\title{
Prevalence of Gastric Cancer Associated with the Epstein-Barr Virus at Brazzaville Chu
}

\section{Fidele Mambouene ${ }^{1}$, Anicet Boumba ${ }^{2}$, Fabien Mouamba ${ }^{3}$, Valere Belle Mbou ${ }^{4}$, Dimitry Moudiongui ${ }^{5}$, Deby Gassaye ${ }^{6}$, Jean Felix Peko ${ }^{7}$}

\author{
${ }^{1} \mathrm{PhD}$ Student Pending Defense in Service at the Pathological Anatomy Laboratory of the University Hospital of \\ Brazzaville \\ ${ }^{2}$ Oncology, Virology and Molecular Biology, General Hospital of Loandjili Pointe Noire \\ ${ }^{3}$ Pathologist and Assistant at the Faculty of Medicine, Pathological Anatomy Laboratory of the University \\ Hospital of Brazzaville \\ ${ }^{4}$ Pathologist and Hospital Practitioner, Poitier Hospital France \\ ${ }^{5}$ PhD Student Pending Defense in Service at the Pathological Anatomy Laboratory of the University Hospital of \\ Brazzaville \\ ${ }^{6}$ Hepato Gastroenterologist in the Gastroenterology Department of the University Hospital of Brazzaville, \\ ${ }^{7}$ Anatomopathologist, Professor at the Faculty of Medicine, Head of Service, Pathological Anatomy Laboratory \\ of the University Hospital of Brazzaville
}

Corresponding Author: Fidele Mambouene

\begin{abstract}
Introduction: Several studies have shown an association between infection with Epstein-Barr virus (EBV) and the occurrence of many cancers in humans, including certain gastric carcinomas (GC). Indeed, recent studies have reported that $10 \%$ of CGs are associated with EBV.

Materials and Methods: Samples of gastric carcinomatous tissues (biopsies and surgical specimens) were analyzed by PCR for the detection of EBV. Samples were collected retrospectively between January 2008 and December 2018.

Results: during this period, 52 samples were analyzed. PCR results show the EBV infection rate to be $3.8 \%$.

Conclusion: The results obtained during this preliminary study confirm the association of EBV in $3.8 \%$ of CG cases, which is consistent with the data in the literature.
\end{abstract}

Keywords: EBV, gastric carcinoma, PCR

\section{INTRODUCTION}

The presence of the Epstein Barr Virus (EBV) in gastric cancer (GC) was first detected by Burke et al. (1990), in a rare form called undifferentiated lymphoid stromal carcinoma, identical to NPC. It was later shown that all other histological types could be associated with EBV (Shibata and Weiss., 1992). This association is based on the one hand on the presence of clonal viral products in gastric tumor cells, and on the other hand on high anti-EBV antibody levels in pre-diagnostic sera. The frequency of CGs infected with EBV ranges from 2 to
$20 \%$, with an average of $10 \%$, making it the largest cluster of EBV-associated tumors in the world. Its incidence is characterized by a significant geographic disparity; it is high in some Western countries such as Germany and the United States, while it is lower in most European countries, South America and Asia (Shinozaki-Ushiku et al. 2015 (a)) . By carrying out this study we wanted to determine the prevalence of the Epstein Barr Virus associated with gastric cancer at the University Hospital of Brazzaville. 


\section{MATERIAL AND METHODS}

We conducted a descriptive study to collect retrospective data made from samples of gastric carcinomatous tissue included in paraffin in the period from January 2008 to December 2018 at the Laboratory of Anatomy Pathology (LAP) of the University Hospital of Brazzaville (CHU) -B). The inclusion criteria were all biopsies and surgical specimens diagnosed with adenocarcinoma. During this period, we collected 52 samples of carcinomatous gastric tissue included in paraffin. The following were excluded: debits that were poorly fixed, over-fixed or insufficient. The association of Epstein bar virus in gastric cancer was verified by quantitative real-time PCR.

The following method was used:

\section{DNA extraction}

Sections of $5 \mu \mathrm{m}$ were produced using the Leica microtome from the paraffin blocks and placed in the eppendorf tubes.

Dewaxing was performed by adding $1 \mathrm{ml}$ of xylene to each eppendorf tube representing a sample. After vortexing for 30 seconds, the tubes were incubated at room temperature for $15 \mathrm{~min}$ then centrifuged at $6000 \mathrm{rpm}$ at $15^{\circ} \mathrm{C}$ for 5 minutes. After removing the supernatant, $1 \mathrm{~mL}$ of $70 \%$ ethanol was added, vortexed, incubated for $15 \mathrm{~min}$ at room temperature then centrifuged for $5 \mathrm{~min}$ at $6000 \mathrm{rpm}$ at 15 - C. The operation was repeated twice. Finally, the pellet was dried at room temperature overnight. The dewaxed and dried pellet was washed with PBS (phosphate buffered saline) two (2) times until no residual ethanol was visible. The samples were resuspended in $180 \mu \mathrm{l}$ of tissue lysis buffer with the addition of $20 \mu \mathrm{l}$ of proteinase $\mathrm{K}$, then vortexed. Incubation took place at $56{ }^{\circ} \mathrm{C}$ for one hour following the manufacturer's instructions. The samples were then cooled to room temperature. Then, we performed 2 to 3 washes by adding $5 \mu \mathrm{l}$ of washing solution followed by centrifugation at 14,000 rpm for 2 minutes. After avid centrifugation, 50 to $100 \mu \mathrm{l}$ of elution solution was added to each collection tube containing a filter followed by a first gentle centrifugation of 2000rpm for one minute, then high speed centrifugation of $8000 \mathrm{rpm}$ for 2 minutes. The collected DNA is immediately stored at $-20^{\circ} \mathrm{C}$ for later use. DNA extraction was performed according to the ReliaPrep TM gDNA Tissue Kit procedure as described by the manufacturer. A Qubit ${ }^{\circledR} \quad 3.0$ spectrophotometer was used to read the concentrations.

\section{2- DNA amplification}

We used the q PCR Mic brand thermal cycler.

\section{Kit composition}

The Amplification Kit used was the Diagenode, it is composed of: a master mix, primers and hydrolysis probe for the Epstein-Barr Diagenode virus, primers and hydrolysis probe for the Diagenode inhibition control and a Diagenode Plasmid Inhibition Control

\section{PCR $25 \mu$ l}

\section{Preparation of the sample}

12.5 ........ X Master mix

$2.5 \mu 1 \ldots \ldots \ldots$..... Primers \& hydrolysis probe for Epstein-Barr Diagenode virus

$2.5 \mu 1 \ldots \ldots \ldots$...... Primers \& hydrolysis probe for Diagenode inhibition control

$2.5 \mu \mathrm{l} \quad \ldots \ldots \ldots . . .$. .Diagenode plasmid inhibition control

$5 \mu 1 \ldots \ldots \ldots . . . .$. Human sample (or VEB positive control)

$25 \mu 1 \ldots . . . . .$. final volume

\section{Thermal cycler program (qMIC)}

ABI 7000-7300-7500-7900HT-

StepOnePlus TM / Roche Lc480 / Biorad iCycler-IQ5- CFX96 / Agilent Stratagene MX3000P-3005P / Qiagen Rotor-Gene

Table 1: qMic program

\begin{tabular}{|l|l|}
\hline Level & Description \\
\hline 1 & 2 minutes at $50^{\circ} \mathrm{C}(1$ cycle $)$ \\
\hline 2 & 10 minutes at $95^{\circ} \mathrm{C}(1$ cycle $)$ \\
\hline 3 & Cycle program $(45$ cycles $)$ \\
& Step $1: 15$ secondes à $95^{\circ} \mathrm{C}$ \\
& Step $2: 60$ secondes à $60^{\circ} \mathrm{C}$ \\
\hline
\end{tabular}




\section{RESULTS}

In our work, during this period from January 2008 to December 2018, we collected 52 cases of gastric adenocarcinoma out of a total of 98 gastric tumors. The results were as follows: the ages of our patients are between 23 and 86 years old. A male predominance is observed with 34 men and 18 women, i.e. a sex ratio of 1.9. Epstein Barr Virus tumor DNA was detected by quantitative real-time polymerase chain reaction in $3.8 \%$ of cases. Both cases were male and according to Lauren's classification these two cases were intestinal histologic type and with age over 50 years

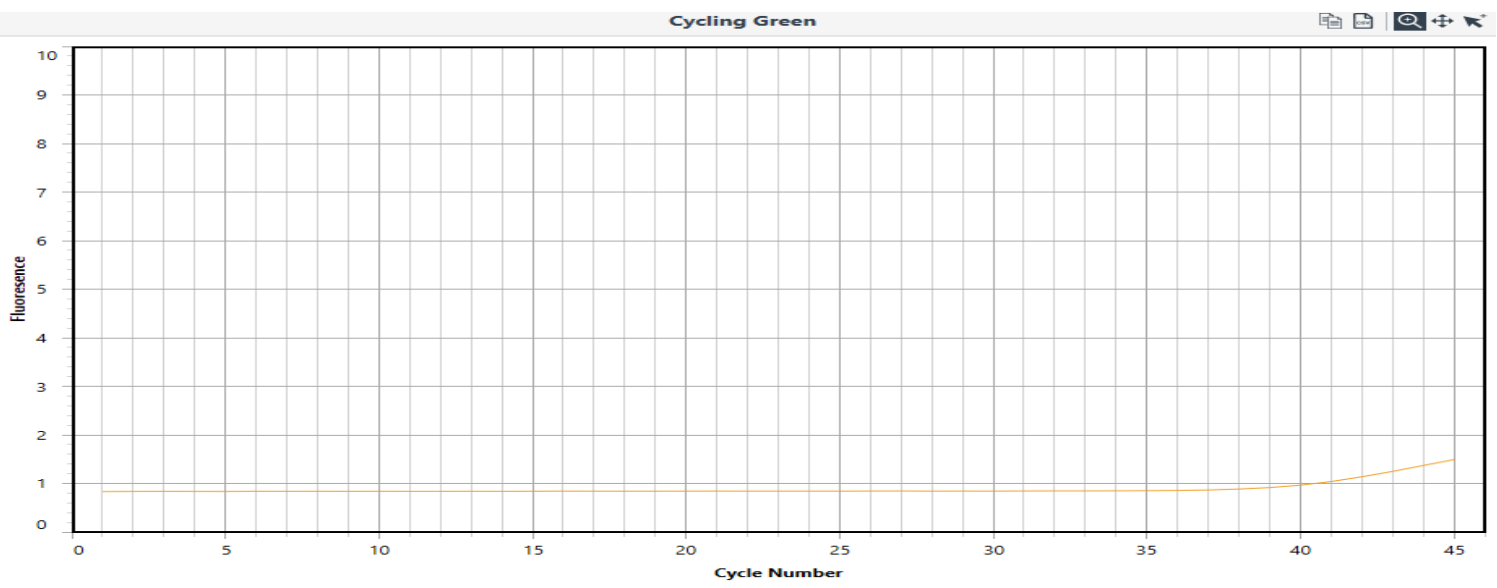

Figure 1: positive case of EBV in gastric cancer (result of the qMIC thermal cycler)

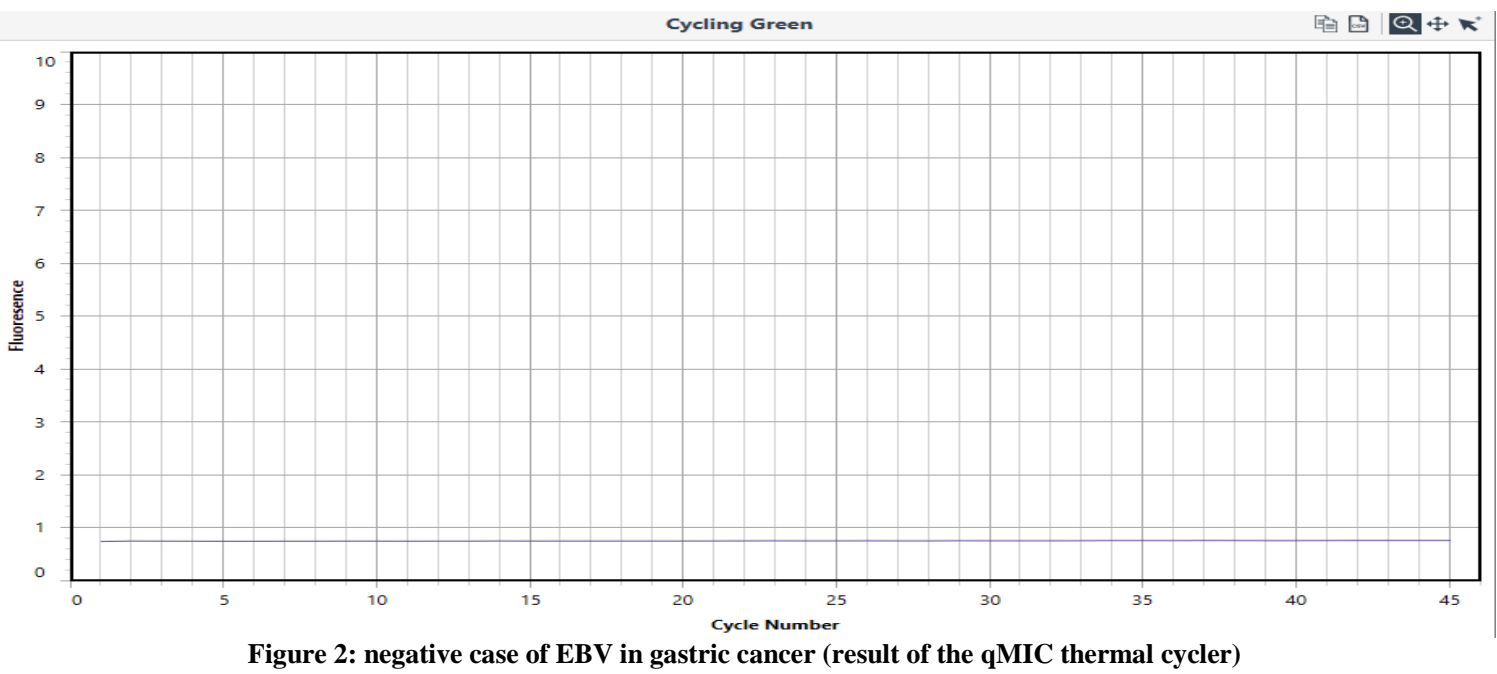

\section{DISCUSSION}

Recently, much attention has been paid to the association of EBV infection and gastric carcinoma. In the present study, two cases of EBV associated with gastric cancer $(3.8 \%)$ were confirmed.

These results are consistent with those reported on the positivity of EBV in gastric carcinoma by zur Hausen and Imai $S$ (zur Hausen A, 2000; Imai S, 1994).

Gastric carcinoma associated with EBV forms the largest group of malignant tumors associated with this virus. It is found worldwide, with large geographic variations (Takada, 2000) .According to metaanalyzes, the frequency of EBV infections in CG ranges from 2 to $20 \%$, with a global average of about $10 \%$ (Xu et al 2016; Wang et al 2016).

The highest frequencies were observed in the United States (16\%) (Shibata and Weiss, 1993; Gulley et al, 1996) and in Germany (18\%) (Ott et al, 1994; Ryan et al, 2009) and lower in Japan (6.9\%) (Takada, 2000), China (4.3\%) (Camago et al, 2011) and Peru (3.9\%). In 
North Africa more precisely in Tunisia, the study carried out by Ben Ayed-Guerali and collaborators in 2011 found a prevalence of 14.8\% (Ben Ayed-Guerfali et al 2011).Thus, taking into account the results of our study, and making the comparison with those of the literature, we can say that our results are in harmony with those of the literature and Congo Brazzaville is a region of low frequency of EBV associated with gastric carcinoma.

\section{CONCLUSION}

This study showed that EBV virus infection is associated with gastric carcinomas in Congo Brazzaville. The frequency of EBV-positive gastric tumors in our study $(3.8 \%)$ is slightly lower than the global average frequency (10\%).

This shows that Brazzaville should be considered a low risk region, suggesting that this virus is not an important etiological factor in the occurrence of gastric cancers in the population of Congo Brazzaville. In the absence of histological or phenotypic peculiarities, detection of EBV positive gastric adenocarcinomas is only possible with molecular biology techniques.

\section{Acknowledgement:}

Sincere thanks to all the dear masters who participated directly or indirectly in the development of this work

\section{Conflict of Interest:}

The authors declare no conflict of interest

\section{Source of Funding: None}

\section{Ethical Approval: Approved}

\section{REFERENCES}

1. Takada K, and Nanbo A. The role of EBERS in oncogenis. Semi cancer $\operatorname{Biol}(2001), 11: 461-467$

2. $\mathrm{Xu} \mathrm{Q}, \mathrm{DU}$ J,and Liu B. Lymphoepithelioma- like gastric carcinoma located in the lesser curvature of the gastric body:A case report and review o the
literature.Mol clin oncol(2016),4(3):405 408

3. Wang ZH, Zhao JJ, and Yuan Z. Lymphoepithelioma- like gastric carcinoma A case report and review of the literature. World j gastroenterol. (2016)(a), 14;22(10): 3056- 61

4. Shibata D,and Weiss LM. Epstein Barr Virus associated gastric adenocarnoma.Am $\mathrm{j}$ pathol(1992), 140,769- 74

5. Gulley ML, Pultzer DL, Eagan PA, and Scheneider BG. Epstein Bar Virus infection is an early event in gastric carcinogenesis and is independent of bcl- 2 expression and p53 accumulation. Hum pathol(1996), 27(1):20-27

6. Ott G, Kirchner T, and Muller- Hermelink HK. Monoclonal Epstei Bar Virus genomes but lack of EBV related protein expression in different types of gastric carcinoma. Histopathology(1994),25(4):323-9

7. Ryan JL, Morgan DR, Dominguez RL,Thorne LB,Elmore SH,Mino-Kenudson M,Lauwers GY,Booker JK, and Gulley ML. Hight level of Epstein bar virus DNA in latently infected gastric adenocarcinoma .Lab invest(2009),89(1):80-90

8. Camago MC,Murphy G,Koriyama C,Peiffer $\mathrm{RM}$,Kim $\mathrm{WH}$, and al.Determinants of Epstein Bar positive gastric cancer:an international Poole analysis.Br $\mathrm{j}$ cancer (2011),28;105(1):38-43

9. Hao Z, Koriyama C, Akiba S, Li J,Luo X, Itoh T,and al. The Epstein Bar Virus associated gastric carcinoma in southem and northem china.Oncol Rep (2002),9:12931298

10. Trimeche M, Ksiâa F, Ziadi S, Mestiri S, Hachana M, Gacem RB, Sriha B, Korbi S .Prevalence and characteristics of EpsteinBarr virus-associated gastric carcinomas in Tunisia.Eur J Gastroenterol Hepatol. 2009 Sep;21(9):1001-7.

11. Kerroucha R, Hervieu V, Chambonnière ML, Mège-Lechevallier F, Poncet G, Boulez J, Tanière $P$, Scoazec JY .Adenocarcinomas of the stomach and distal esophagus, Incidence and phenotypic characteristics of EBV-associated cases in the Lyons area, France. .Ann Pathol. 2004 Jun;24(3):228-35

12. Fukayama M. Epstein-Barr virus and gastric carcinoma. Pathol Int. 2010 May;60(5):33750 
13. Akiba S, Koriyama C, Herrera-Goepfert R, Eizuru Y .Epstein-Barr virus associated gastric carcinoma: epidemiological and clinicopathological features. Cancer Sci. $2008 \mathrm{Feb}$;99(2):195-201

14. Osato $\mathrm{T}$, Imai $\mathrm{S}$.Epstein-Barr virus and gastric carcinoma. Semin Cancer Biol. 1996 Aug;7(4):175-82.

15. Morewaya J, Koriyama C, Akiba S, Shan D, Itoh T, Eizuru Y.Epstein-Barr virusassociated gastric carcinoma in Papua New Guinea. Oncol Rep. 2004 Nov;12(5):1093-8

16. Kattoor J, Koriyama C, Akiba S, Itoh T, Ding S, Eizuru Y, Abraham EK, Chandralekha B, Amma NS, Nair MK.J. .Epstein-Barr virus-associated gastric carcinoma in southern India: A comparison with a large-scale Japanese series. Med Virol. 2002 Nov;68(3):384-9

17. Myung Ah Lee, Young Seon Hong, Jin Hyoung Kang et al. Detection of EpsteinBarr Virus by PCR and Expression of LMP1, p53, CD44 in Gastric Cancer. Korean J Intern Med. 2004 Mar; 19(1): 4347.
18. Bing Luo, Yun Wang, Xiao-Feng Wang, Hua Liang, Li-Ping Yan, Bao-Hua Huang, and Peng Zhao. genes in EBVassociated gastric carcinomas. World $\mathrm{J}$ Gastroenterol. 2005 Feb 7; 11(5): 629-633.

19. zur Hausen A, Brink AA, Craanen ME, Middeldorp JM, Meijer CJ, van den Brule AJ. Unique transcription pattern of EpsteinBarr virus (EBV) in EBV-carrying gastric adenocarcinomas: expression of the transforming BARF1 gene. Cancer Res. 2000;60:2745-2748.

20. Imai S, Koizumi S, Sugiura M, Tokunaga M, Uemura Y, Yamamoto N, Tanaka S, Sato E, Osato T. Gastric carcinoma: monoclonal epithelial malignant cells expressing Epstein-Barr virus latent infection protein. Proc Natl Acad Sci USA. 1994;91:9131-9135.

How to cite this article: Mambouene F, Boumba A, Mouamba $F$ et.al. Prevalence of gastric cancer associated with the Epstein-Barr virus at Brazzaville Chu. Int J Health Sci Res. 2021; 11(9):137-141. DOI: https://doi.org/10.52403 /ijhsr.20210921 